\title{
MANAJEMEN PEMBELAJARAN KITAB KUNING DI MTs RAUDLATUL ULUM GUYANGAN TRANGKIL PATI
}

\author{
Salafi \\ Universitas Islam Negeri Walisongo Semarang \\ salafi.ambari@gmail.com
}

\begin{abstract}
ABSTRAK
Penelitian ini bertujuan untuk menganalisis manajemen pembelajaran Kitab kuning di Madrasah Tsanawiyah Raudlatul Ulum Guyangan Trangkil Pati. Ada tiga hal yang menjadi fokus penelitian ini yaitu perencanaan, pengorganisasian, dan evaluasi pembelajaran kitab kuning. Penelitian ini merupakan penelitian lapangan dengan pendekatan kualitatif. Karena itu, pengumpulan data dilakukan dengan teknik observasi, wawancara, dan dokumentasi. Untuk menganalisis data, peneliti menggunakan metode deskriptif kualitatif dengan pendekatan fenomenologi. Analisis data dilakukan dengan tiga tahapan, yaitu display, reduksi, dan verifikasi. Hasil penelitian menunjukkan model pengembangan manajemen terdiri tiga unsur yaitu perencanaan, pengorganisasian, dan evaluasi. Perencanaan di MTs Raudlatul Ulum Guyangan Trangkil Pati dilakukan di setiap awal tahun untuk menyusun program kerja dan kurikulum. Dalam hal ini, Madrasah mendatangkan ahli sebagai konsultan perencanaan program dan kurikulum. Pengorganisasian pembelajaran kitab kuning dilakukan dengan memberikan jam tambahan setiap Sabtu sampai Selasa untuk mengakomodir semua mata pelajaran. Adapun fungsi evaluasi dilakukan dengan penilaian tengah dan akhir semester dalam bentuk ujian tulis, lisan, dan hafalan.
\end{abstract}

Kata Kunci: Manajemen, Pembelajaran, Kitab Kuning.

\begin{abstract}
This study aims to analyze the management of the yellow book learning at Madrasah Tsanawiyah Raudlatul Ulum Guyangan Trangkil Pati. Three things are the focus of this research, namely planning, organizing, and evaluating the yellow book learning. This research is field research with a qualitative approach. Therefore, data collection was carried out using observation, interview, and documentation techniques. To analyze the data, researchers used a qualitative descriptive method with a phenomenological approach. Data analysis was carried out in three stages, namely display,
\end{abstract}


reduction, and verification. The results showed that the management development model consisted of three elements, namely planning, organizing, and evaluating. Planning at MTs Raudlatul Ulum Guyangan Trangkil Pati is carried out at the beginning of each year to prepare work programs and curricula. In this case, Madrasahs bring in experts as program and curriculum planning consultants. The yellow book learning organization is done by providing additional hours every Saturday to Tuesday to accommodate all subjects. The evaluation function is carried out by assessing the middle and end of the semester in the form of written, oral, and rote exams.

Keywords: Management, Learning, Yellow Book.

\section{PENDAHULUAN}

Keberhasilan masyarakat tentu tidak bisa dilepaskan dari keberhasilan seluruh organisasi yang terdapat dalam kehidupan masyarakat tersebut. Sedangkan keberhasilan organisasi ditentukan oleh bagaimana organisasi tersebut dikelola untuk mencapai tujuan yang telah ditetapkan (Tunggal, 1993: 3). Dalam dunia pendidikan pun demikian, Keberhasilan penyelenggaraan pendidikan di sebuah institusi hakekatnya tidak terlepas dari pengelolaan yang efektif dan efisien untuk mencapai tujuan. Karena itu, manajemen pendidikan memiliki peranan yang sangat krusial dalam mencapai tujuan pendidikan. Mulyasa (2000) juga menegaskan bahwa manajemen merupakan komponen integral yang tidak dapat terpisahkan dari proses pendidikan secara keseluruhan. Tanpa manajemen yang baik hampir mustahil tujuan pendidikan dapat dicapai secara efektif dan efisien.

Pembelajaran sebagai ujung tombak penyelenggaraan pendidikan juga tidak bisa dilepaskan dari manajemen. Hal ini karena pembelajaran adalah suatu kombinasi yang tersusun dari berbagai unsur baik manusiawi, material, sarana prasarana, dan prosedur untuk mencapai tujuan pembelajaran. Komponen-komponen tersebut saling berkaitan dan saling melengkapi satu sama lain sehingga pembelajaran dapat berjalan dengan baik. Jika ada salah satu komponen yang tidak berfungsi, maka proses pembelajaran juga akan terhambat (Rohman, 2019: 10). Maka, agar unsurunsur tersebut bisa berjalan sesuai fungsinya secara proporsional dan saling melengkapi, kegiatan pembelajaran juga membutuhkan manajemen.

Manajemen sendiri sering diartikan secara harfiah sebagai seni mengatur atau mengelola. Tidak jauh beda, secara terminologi manajemen berarti proses pengendalian dan pemanfaatan semua faktor dan sumber daya untuk mencapai 
tujuan tertentu (Manullang, 2014). Pendapat lain mengatakan bahwa manajemen adalah proses merencanakan, mengorganisasikan, memimpin dan mengendalikan pekerjaan anggota organisasi untuk mencapai sasaran organisasi yang sudah ditetapkan (Stoner, Freeman, \& Gilbert, 1996: 16). Definisi ini sejalan dengan fungsifungsi dalam manajemen yaitu perencanaan (planning), pengorganisasian (organizing), penataan staff (staffing), memimpin (leading), memfasilitasi (facilitating), memperdayakan staf (empowering) dan pengawasan (controlling) (Syukur, 2011: 9).

Dalam konteks pembelajaran, manajemen secara sempit bisa diartikan sebagai proses pengelolaan guru terhadap berbagai kegiatan selama proses pelaksanaan pembelajaran. Sementara dalam arti luas, manajemen pembelajaran adalah kegiatan mengelola pembelajaran mulai dari perencanaan, pengorganisasian, pengarahan atau pengendalian, dan penilaian (Rukajat, 2018: 5).

Dengan demikian, manajemen tidak mungkin bisa dipisahkan dari proses pembelajaran itu sendiri. Manajemen dibutuhkan agar pembelajaran bisa berjalan secara terarah dan sesuai dengan tujuan yang telah ditetapkan. Kegagalan mencapai tujuan pembelajaran, tidak semata-mata karena faktor rendahnya kemampuan peserta didik, tetapi bisa juga disebabkan karena proses pembelajaran yang tidak efektif dan efisien. Di sinilah, manajemen pembelajaran sangat dibutuhkan untuk menunjang pencapaian terhadap tujuan pembelajaran (Manullang, 2014).

MTs Raudlatul Ulum Guyangan Trangkil Pati merupakan salah satu Madrasah Tsanawiyah di daerah Pantura yang telah masyhur dengan pembelajaran Kitab kuningnya. Madrasah yang terintegrasi dengan pesantren ini, selain menerapkan kurikulum kitab kuning dalam kegiatan intrakurikuler di kelas, juga menyelenggarakan pembelajaran kitab kuning melalui kegiatan ekstrakurikuler dan kegiatan pesantren. Terbukti sederet prestasi dalam bidang kitab kuning telah diraih oleh peserta didik MTs Raudlatul Ulum. Madrasah yang terletak di Desa Guyangan Trangkil Pati ini pernah menyabet Juara I Musabaqah Qira'atul Kutub tingkat Propinsi pada tahun 2017 dan tingkat nasional pada tahun 2018.

Pembelajaran kitab kuning di MTs Raudlatul Ulum, selain bertujuan untuk mencetak para ahli agama, juga dipersiapkan untuk mencetak lulusan yang siap melanjutkan pendidikan ke luar negeri. Hal ini karena MTs dan MA Raudlatul Ulum merupakan salah satu madrasah di Indonesia yang mendapatkan mu'adalah (akreditasi) dari Universitas Al-Azhar Kairo. MTs yang mu'adalah oleh al-Azhar dianggap sejajar dengan Madrasah l'dadiyah sedangkan MA sejajar dengan 
92 | Tarbawi : Jurnal Pendidikan Islam Vol. 17. No. 2. Juli - Desember 2020

Madrasah Tsanawiyah di Mesir. Setiap tahun MA Raudlatul Ulum ini memberangkatkan 20-25 lulusannya untuk studi di Al-Azhar. Dengan begitu, sangat wajar jika pembelajaran kitab kuning di MTs Raudlatul Ulum dikelola sedemikian rupa agar lulusan MTs mampu menyesuaikan diri dengan kurikulum MA yang telah terakreditasi Al-Azhar.

Prestasi ini sedikit banyak menunjukkan gambaran kualitas pembelajaran kitab kuning di Madrasah tersebut. Tentu saja, kualitas tersebut tidak bisa dilepaskan dari manajemen pembelajaran yang diterapkan. Menurut Eko Widinarko, Kepala MTs Raudlatul Ulum, manajemen pembelajaran kitab kuning dilaksanakan melalui tiga tahapan, yaitu perencanaan pelaksanaan, pengawasan atau evaluasi. Meskipun berlatar belakang pesantren, tetapi manajemen yang diterapkan dalam pembelajaran kitab kuning di MTs Raudlatul Ulum sama seperti pembelajaran mata pelajaran lain. la mengatakan: "Pembelajaran kitab kuning juga kita kelola seperti pembelajaran lain. Ada perencanaannya, kurikulumnya jelas, targetnya juga jelas untuk tiap jenjang".

Berangkat dari latar belakang inilah, penulis tertarik untuk mengeksplore lebih jauh terhadap manajemen yang diterapkan di MTs Raudlatul Ulum Guyangan Trangkil Pati. Sebab, tidak banyak madrasah di Indonesia yang memiliki predikat mu'adalah dari Universitas sekelas Al-Azhar. Hasil penelitian ini diharapkan dapat memberikan tawaran model manajemen pembelajaran kitab kuning yang bisa diadopsikan di madrasah lain.

\section{METODE PENELITIAN}

Penelitian ini adalah penelitian lapangan (field research) yang bersifat kualitatif, yaitu suatu penelitian yang akan menggambarkan data dan fakta apa adanya yang ditemukan di lapangan untuk menggambarkan manajemen pembelajaran kitab kuning di MTs Raudlatul Ulum Guyangan Trangkil Pati. Data dikumpulkan melalui observasi, wawancara, dan dokumentasi. Observasi dilakukan dengan mengamati pembelajaran di MTs Raudlatul Ulum Guyangan Trangkil Pati secara langsung, baik intra maupun ekstrakurikuler. Wawancara dilakukan dengan kombinasi terstruktur dan tidak terstruktur. Informan utama dalam hal ini adalah KH. M. Najib Suyuthi sebagai Ketua Yayasan, Eko Wijanarko selaku Kepala Madrasah, dan Mukhashish sebagai Wakil Kepala Madrasah bidang kurikulum. Adapun dokumentasi dilakukan dengan mengggali dokumen-dokumen kelembagaan, perangkat pembelajaran, dan tulisantulisan yang relevan. Untuk menguji keabsahan data tersebut peneliti menggunakan 
teknik triangulasi meliputi triangulasi sumber dan waktu. Data kemudian dianalisis secara deskriptif menggunakan pendekatan fenomenologi. Analisis data dilakukan melalui tiga tahapan, yakni display atau penyajian data, reduksi, dan verifikasi.

\section{PEMBAHASAN}

\section{Manajemen pembelajaran}

Kamus bahasa Indonesia mengartikan manajemen dengan proses pemakaian sumber daya secara efektif untuk mencapai sasaran yang telah ditentukan (Pusat Bahasa, 2008: 980). Sementara itu, Wibowo memaknai manajemen sebagai suatu proses untuk membuat aktivitas terselesaikan secara efisien dan efektif dengan dan melalui orang lain (Wibowo, 2012: 9). Pendapat lain mengatakan manajemen sebagai pengelolaan, penyelenggaraan, ketatalaksanaan penggunaan sumber daya secara efektif untuk mencapai tujuan atau sasaran yang diinginkan. Dengan kata lain manajemen adalah proses perencanaan, pengorganisasian, kepemimpinan dan pengendalian untuk mencapai tujuan yang telah ditetapkan secara efektif dan efisien (Sufyarma, 2004: 188)

Jika merujuk definisi di atas, manajemen dalam konteks pembelajaran bisa diartikan sebagai pemanfaatan proses pemakaian sumber daya belajar secara efektif untuk mencapai tujuan pembelajaran yang telah ditentukan. Pendapat lain mengatakan bahwa manajemen secara sempit bisa diartikan sebagai proses pengelolaan guru terhadap berbagai kegiatan dalam pembelajaran untuk mencapai tujuan. Sementara dalam arti luas, manajemen pembelajaran adalah kegiatan mengelola pembelajaran mulai dari perencanaan, pengorganisasian, pengarahan atau pengendalian, dan penilaian (Rukajat, 2018: 8).

Manajemen Pembelajaran melibatkan 3 fungsi pokok, antara lain 1) Merencanakan, yaitu menyusun seperangkat rencana dan pengaturan kegiatan pembelajaran, media, sumber, waktu, dan penilaian. Fungsi perencanaan biasanya dilakukan dengan mengembangkan rencana tahunan, rencana semester, rencana bagian (pokok bahasan), rencana mingguan dan rencana harian (rencana pelajaran). 2) Mengorganisasikan, yaitu menghubungkan atau menggabungkan semua sumber daya pembelajaran untuk mencapai mencapai tujuan yang ditetapkan. 3) Mengawasi yaitu melakukan kontrol terhadap proses pembelajaran dan mengukur apakah pembelajaran sudah mencapai tujuan atau belum. Pengawasan bisa dilakukan dengan evaluasi terhadap proses dan hasil pembelajaran. (Maria \& Sediyono, 2017). 
Ketiga fungsi di atas merupakan fungsi-fungsi yang harus dijalankan oleh guru dalam perannya sebagai manajer. Guru sebagai manajer pembelajaran berarti bahwa guru sebagai pengelola unsur-unsur pembelajaran baik sumber belajar, waktu, media, maupun organisasi kelas. Tugas manajerial guru dimulai sebelum pembelajaran dimulai dengan menyusun perencanaan, kemudian pengorganisasian, hingga pengawasan dan penilaian (Ilahi \& Imaniyati, 2016).

\section{Sekilas tentang MTs Raudlatul Ulum Guyangan Pati}

Madrasah Tsanawiyah atau MTs Raudlatul Ulum adalah salah satu sekolah menengah pertama berciri khas Islam yang berada di bawah naungan Yayasan Perguruan Islam Raudlatul Ulum Guyangan Trangkil Pati. Madrasah ini terletak di desa Guyangan Kecamatan Trangkil atau Jalan Raya Juwana-Tayu kilometer 07 Pati, sekitar 15 km dari pusat kota Pati. Selain mengelola MTs, yayasan ini juga mengelola Pesantren, MI, MA, dan madrasah diniyah.

Cikal bakal madrasah ini diawali dengan berdirinya Madrasah Manba'ul Ulum yang dipelopori oleh KH. Suyuthi Abdul Qodir pada tahun 1929. Adanya tekanan dari pemerintah kolonial Belanda waktu itu, mengakibatkan kondisi tidak lagi memungkinkan untuk mengembangkan lembaga pendidikan berbasis rakyat. Madrasah Manba'ul Ulum pun akhirnya tutup total sekitar tahun 1940-an. Pasca kemerdekaan RI, dengan dorongan para ulama dan tokoh masyarakat, Madrasah Manba'ul Ulum yang mati suri, selanjutnya dihidupkan kembali pada tahun 1950 dengan nama "Raudlatul Ulum".

Pada masa-masa awal berdirinya, madrasah ini membuka kelas shifir awal, shifir tsani, dan shifir tsalits. Pada tahun 1962, format madrasah kemudian dirubah menjadi Pendidikan Guru Agama Pertama (PGAP) empat tahun dan takhassush 2 tahun. Perubahan sistem pendidikan nasional kemudian juga turut mengubah sistem pendidikan Madrasah Raudlatul Ulum menjadi PGAP empat tahun dan PGAL (Pendidikan Guru Agama Lanjutan) 2 tahun.

Demi penguatan dan pengembangan pendidikan ke depan, maka pada tahun 1972 didirikan yayasan berbadan hukum dengan nama Yayasan Perguruan Islam Raudlatul Ulum. Selang dua tahun, yakni tahun 1974, madrasah mengalami perubahan format untuk kesekian kalinya, dari PGAP 4 tahun dan PGAL 2 tahun menjadi Madrasah Tsanawiyah 3 tahun dan Madrasah Aliyah 3 tahun dan tidak mengalami perubahan lagi hingga saat ini. Semenjak berdirinya tahun 1950 hingga 
berkembang menjadi sebuah yayasan besar, tampuk kepemimpinan Raudlatul Ulum selalu dipegang oleh keluarga pendiri. Mulai dari KH. Suyuthi Abdul Qadir sebagai pendiri, kemudian digantikan oleh KH. Salim Suyuthi, kemudian KH. Humam Suyuthi, dan sekarang dipimpin oleh KH. M. Najib Suyuthi.

MTs Raudlatul Ulum merupakan salah satu madrasah tertua dan terbesar di kota Pati. Sekian prestasi mulai tingkat lokal hingga tingkat nasional sudah sering dicicipi. Salah satu keunggulan madrasah ini terletak pada pembelajaran kitab kuning dan bahasa asing. Untuk pembelajaran kitab kuning, selain menjadi muatan lokal di Madrasah, juga dilaksanakan melalui program ekstrakurikuler dan majlis ta'lim pondok pesantren. Sedangkan untuk program penguatan bahasa, madrasah ini memiliki LPPBA (Lembaga Pendidikan dan Pelatihan Bahasa Arab) untuk Bahasa Arab dan English Corversation Club untuk Bahasa Inggris.

Saat ini MTs Raudlatul Ulum memiliki sekitar 1500-an peserta didik secara keseluruhan mulai kelas VII hingga IX. Jumlah yang sangat besar untuk ukuran Madrasah Tsanawiyah. Tetapi, melihat sejarah dan prestasi Yayasan Raudlatul Ulum secara umum, jumlah peserta didik sebanyak itu bukanlah hal yang aneh. Para peserta didik tersebut rata-rata berasal dari daerah Pati dan sekitarnya seperti Kudus, Jepara, Demak, Rembang dan sebagian dari luar provinsi.

\section{Manajemen Pembelajaran kitab kuning di MTs Raudlatul Ulum}

1. Fungsi Perencanaan

Kegiatan perencanaan pembelajaran di MTs Raudlatul Ulum dilaksanakan di setiap awal tahun pelajaran. Langkah pertama yang dilakukan adalah peninjauan kurikulum. Dalam hal ini, pihak yayasan mendatangkan ahli atau konsultan pendidikan untuk memberikan pengarahan dan motivasi kepada kepala madrasah, wakil-wakilnya dan semua guru tentang pengembangan kurikulum. Selain itu, peninjauan kurikulum ini juga melibatkan beberapa unsur-unsur manajemen Madrasah, antara lain kepala madrasah, wakil kepala bidang kurikulum, wakil kepala bidang prasarana dan sarana, wakil kepala bagian kepesertadidikan, wakil kepala bagian hubungan masyarakat, koordinator B.P, kepala T.U, dan komite madrasah.

Peninjauan kurikulum ini sendiri dimaksudkan untuk mengkaji kurikulum yang berlaku di madrasah dan kesesuaiannya dengan kebutuhan masyarakat dan tuntutan perkembangan zaman. Kurikulum MTs Raudlatul Ulum sendiri merupakan 
perpaduan antara kurikulum Kemendikbud, Kemenag, dan kurikulum muatan lokal berbasis pesantren. KH. M. Najib Suyuthi, sebagai ketua yayasan mengatakan:

"MTs Raudlatul Ulum mengkombinasikan antara kurikulum Kemendikbud, Kemenag dan Muatan Lokal berupa kurikulum Pondok Pesantren. Kurikulum muatan lokal ini kami pertahankan semenjak berdirinya Raudlatul Ulum hingga saat ini. Kalau kurikulum ada di SMA atau MAN itu ada disini, tetapi yang muatan lokal otomatis tidak ada pada mereka."

Selain dua kegiatan tersebut, fungsi perencanaan dalam manajemen pembelajaran di MTs Raudlatul Ulum juga dilakukan dengan merancang program pembelajaran meliputi penyusunan kalender akademik, program tahunan, program semester, dan program harian. Semua guru baik pengampu pelajaran umum, pelajaran PAl, maupun muatan lokal diwajibkan menyusun perangkat pembelajaran pada awal semester yang disahkan kepala madrasah. Dengan kata lain, pembelajaran kitab kuning sebagai muatan lokal juga direncanakan sedemikian rupa oleh madrasah sebagaimana mata pelajaran lain. Berikut ini adalah kurikulum muatan lokal berbasis pesantren di MTs Raudlatul Ulum Guyangan Pati:

Tabel 1. Kurikulum Muatan Lokal MTs Raudlatul Ulum

\begin{tabular}{c|ll}
\hline No & \multicolumn{1}{|c}{ Mata Pelajaran } & \multicolumn{1}{c}{ Kitab } \\
\hline 1 & Fiqh & Tuhfah al-Thulab \\
2 & Ushul Fiqih & Lathaif al-Isyarat \\
3 & Ilmu Balaghah & al-Jauhar al-Maknun \\
4 & Tafsir & Tafsir al-Jalalain \\
5 & Tauhid & Dalail al-Tauhid \\
6 & Akhlak & Ta'lim al-Muta'alim \\
7 & Hadits & Bulugh al-Maram \\
8 & Ilmu Faraid & Matan al-Rohabiyah \\
9 & Nahwu Sharaf & Alfiyyah Ibnu Malik \\
10 & Ilmu Falak & Durus al-Falakiyah \\
11 & Ilmu Mustholah al hadits & Minhat al-Mughits \\
12 & Ilmu 'Arudl & Muhtasyar Syafi \\
\hline
\end{tabular}

Dari tabel di atas bisa dilihat bahwa kurikulum muatan lokal di MTs Raudlatul Ulum terdiri dari 12 mata pelajaran agama yang bercorak pesantren karena 
menggunakan kitab kuning sebagai sumber belajar. Ini menegaskan corak MTs Raudlatul Ulum yang selain mengusung sistem pendidikan modern juga tetap memegang teguh karakter aslinya, yaitu karakter klasik berbasis pesantren.

2. Fungsi Pengorganisasian

Adanya perpaduan antara kurikulum Kemendikbud, Kemenag, dan Muatan lokal yang diberlakukan di MTs Raudlatul Ulum praktis membutuhkan jam pelajaran yang tidak sedikit. Karena itu, pihak madrasah memberlakukan jam tambahan untuk mengakomodir mata pelajaran muatan lokal agar bisa berjalan seimbang sebagaimana mata pelajaran lain. Jam tambahan tersebut dilaksanakan mulai jam 13.30 sampai dengan jam 17.00. setiap Sabtu sampai Selasa. Hanya saja antara peserta didik putra dan putri dibedakan harinya. Untuk peserta didik putra, jam tambahan diadakan setiap Sabtu, Ahad, dan Senin, sementara untuk putri setiap hari Ahad, Senin, dan Selasa. Hal ini sebagaimana disampaikan oleh Kepala MTs, Eko Widinarko:

"Ya karena di sini ada sekitar 30 mata pelajaran, jadi pembelajaran tidak mungkin dilaksanakan sesuai jam sekolah seperti yang lain. Karena itu kami adakan jam tambahan dari jam 13.30 sampai jam 17.00 setiap Sabtu, Ahad, Senin untuk peserta didik putra dan untuk putri setiap Ahad, Senin, Selasa.”

Sebagai madrasah yang terintegrasi dengan dan lahir dari rahim pesantren, pembelajaran kitab kuning sebagai kurikulum muatan lokal di MTs Raudlatul Ulum dilaksanakan dengan model pembelajaran pesantren. Secara umum, pembelajaran kitab kuning di MTs Raudlatul Ulum dilaksanakan dengan model bandongan. Bandongan merupakan salah satu model pembelajaran khas pesantren tradisional yang tidak bisa ditemukan di pesantren modern (Nurtawab, 2019). Bandongan diterapkan dengan cara guru membaca teks kitab kuning dan menterjemahkannya kata perkata ke dalam bahasa Jawa. Setelah itu, guru menjelaskan kandungan dari teks kitab kuning tersebut. Sementara peserta didik menulis artinya atau biasa disebut ngapsahi di badan kitab dengan makna gandul.

Selain bandongan, pembelajaran kitab kuning di MTs raudlatul Ulum juga dilaksanakan dengan model sorogan. Satu persatu peserta didik diminta untuk membaca teks kitab kuning di depan kelas atau di hadapan guru serta menerjemahkannya ke dalam bahasa Jawa. Sementara guru dan peserta didik lain 
menyimak dan mengkoreksi bacaan peserta didik tersebut jika terdapat bacaan yang salah.

Sama halnya dengan bandongan, model sorogan juga hanya bisa ditemukan di pesantren salaf. Model ini merupakan model pembelajaran harfiahtekstual yang menekankan kemampuan penerjemahan secara detail. Dari model ini diharapkan para santri mampu menangkap arti dan fungsi kata demi kata dalam kitab kuning dengan detail (Abdurrahman, 2020). Dua model di atas merupakan metode yang sudah sangat tua, setua pesantren di Indonesia dan telah terbukti mampu meningkatkan kemampuan membaca kitab kuning (Mu'izzuddin, Juhji, \& Hasbullah, 2019).

Selain dua model pembelajaran tersebut, pembelajaran kitab kuning di MTs Raudlatul Ulum juga menerapkan model hafalan. Namun model ini tidak diterapkan pada semua materi pembelajaran kitab kuning, hanya khusus untuk kitab-kitab kuning bergenre nadzam atau syair. Khusus untuk kitab Alfiyyah ibn Malik, wajib dihafalkan dan menjadi syarat kenaikan kelas bagi peserta didik.

Kitab Alfiyyah ibn Malik merpakan kitab bergenre nadzam yang membahas tentang gramatika Arab (Nahw dan Sharf). Dinamakan Alfiyyah yang berarti kitab yang serba seribu, karena kitab ini berisi 1002 bait nadzam. Di kalangan pesantren, Alfiyyah merupakan salah satu kitab legendaris sekaligus primadona dalam kajian IImu nahwu dan sharf. Mempelajari kitab Alfiyyah menjadi prestise tersendiri bagi para santri dan terkadang menjadi ukuran kemampuan santri. Santri yang sudah hafal Alfiyyah dianggap telah memiliki kemampuan yang cukup tinggi (Muhid, Asnawi, \& $\mathrm{P}, 2018)$.

Karena Alfiyyah ibn Malik berisi 1002 bait, maka akan sulit untuk menghafalkan bait sebanyak itu dalam watu setahun pelajaran. Apalagi jika melihat beban belajar peserta didik karena masih ada mata pelajaran lain baik umum maupun agama. Karena itu, pihak madrasah menetapkan jumlah bait di setiap jenjang yang harus dihafalkan. Untuk kelas VII, wajib menghafal 320 bait, kelas VIII 320 bait, dan kelas IX 362 bait, sehingga saat lulus dari MTs, hafalan sudah genap menjadi 1000 bait. Pada pelaksanaannya, peserta didik wajib menyetorkan hafalan sebanyak 10 bait Alfiyyah kepada ustadz setiap seminggu sekali.

Di luar dua model tersebut, kegiatan pembelajaran kitab kuning di MTs Raudlatul Ulum juga menggunakan model musyawarah. Namun model ini tidak digunakan dalam pembelajaran intrakurikuler di dalam kelas, tetapi digunakan 
dalam kegiatan ekstrakurikuler pendalaman kitab kuning yang dilaksanakan setiap malam selasa. Musyawarah merupakan salah satu model khas pesantren salaf yang menekankan pada pembahasan masalah-masalah dan pemecahannya. Model ini bertujuan untuk mempertajam analisis santri terhadap isi kitab dan pemecahan berbagai masalah faktual (Rohman, 2017) .

3. Fungsi Pengawasan

Controlling atau pengawasan merupakan salah satu unsur manajemen yang krusial sebab menjadi jembatan terakhir dalam rantai fungsional dalam kegiatan manajemen. Pengawasan dilakukan untuk mengetahui efektifitas kegiatan yang dilakukan sebagai landasan untuk perbaikan kegiatan yang akan datang. Dengan demikian, bisa dikatakan fungsi pengawasan dalam manajemen tidak jauh berbeda dengan evaluasi.

Evaluasi pembelajaran kitab kuning di MTs Raudlatul Ulum dilakukan sesuai program tahunan dan semester yang telah ditetapkan. Penilaian dilakukan dalam tiga bentuk, yaitu penilaian harian, penilaian tengah semester, dan penilaian akhir semester. Penilaian dilakukan dalam bentuk ujian tertulis yang dirancang sendiri oleh guru pengampu. Khusus untuk mata pelajaran nahwu dan sharaf yang menggunakan kitab Alfiyyah ibn Malik, selain ujian tulis juga diadakan ujian lisan berupa hafalan.

Disampaikan oleh Mukhashish bahwa evaluasi pembelajaran kitab kuning dilaksanakan dengan tiga bentuk, yaitu tulis, lisan, dan hafalan.

“Untuk pembelajaran kitab kuning, penilaiannya sama dengan mata pelajaran lain, yaitu di tengah semester dan akhir semester. Bentuknya bisa tulis, lisan, dan hafalan untuk Alfiyyah. Hal ini agar penguasaan peserta didik terhadap kitab kuning benar-benar matang."

Untuk penilaian akhir semester atau kenaikan kelas, ada beberapa kriteria yang harus dipenuhi peserta didik agar bisa naik kelas, antara lain:

1. Kriteria ketuntasan minimal (KKM) yang ditetapkan oleh pihak madrasah untuk setiap mata pelajaran adalah 7,5. Maka, peserta didik harus mencapai nilai tersebut jika ingin naik kelas.

2. Di akhir tahun pelajaran, peserta didik harus menyelesaikan hafalan Nadzam Alfiyyah ibn Malik sesuai porsi yang telah ditetapkan, yaitu 320 bait untuk kelas VII, 320 bait untuk kelas VIII, dan 362 bait untuk kelas IX. 
3. Dari sisi perilaku, setiap peserta didik tidak boleh memperoleh nilai buruk (C) dalam kelakuan, kerajinan, kedisiplinan dan kerapian.

Dikonfimasi oleh Eko Widinarko, bahwa fungsi penilaian tersebut merupakan bagian dari upaya Madrasah untuk mengontrol ketercapaian visi MTs Raudlatul Ulum yaitu Maju dalam prestasi melalui ilmu amaly dan amal ilmy. Maksudnya, mencetak peserta didik yang menguasai ilmu pengetahuan dan mampu mempraktikkan keilmuannya dalam kehidupan sesuai dengan konteks perkembangan zaman.

\section{SIMPULAN}

MTs Raudlatul Ulum Guyangan Trangkil Pati merupakan salah satu madrasah tertua dan terbesar yang lahir dari tradisi pesantren salaf. Karena itu, pembelajaran kitab kuning di madrasah ini menjadi salah satu program unggulan sekaligus karakteristik yang membedakannya dengan madrasah lain. Ini dibuktikan dengan predikat mu'adalah yang diraih oleh MTs dan MA Raudlatul Ulum selama bertahuntahun hingga sekarang. Pembelajaran kitab kuning tetap dijaga dan dilestarikan sebagai kurikulum muatan lokal meskipun tuntutan untuk mengikuti kurikulum pemerintah tidak bisa diabaikan. Dengan kata lain perkembangan dan perubahan pendidikan nasional dari waktu ke waktu tidak menggerus ciri khas MTs Raudlatul Ulum dengan pendidikan islam tradisionalnya. Ini bisa menjadi cermin bagi madrasah lain terutama yang berbasis pesantren untuk tidak kehilangan jati dirinya sebagai sebagai sekolah berciri khas Islam.

\section{DAFTAR PUSTAKA}

Abdurrahman. (2020). Genealogi Metode Sorogan (Telisik Historis Metode Pembelajaran dalam tradisi Pesantren). Jurnal Studi Pesantren, 1(1), 1-14.

Ilahi, N. W., \& Imaniyati, N. (2016). Peran Guru Sebagai Manajer dalam Meningkatkan Efektivitas Proses Pembelajaran. Jurnal Pendidikan Manajemen Perkantoran, 1(1), 99. https://doi.org/10.17509/jpm.v1i1.3343

Manullang, M. (2014). Manajemen Pembelajaran Matematika. Jurnal Pendidikan dan Pembelajaran, 21(2), 208-2017.

Maria, E., \& Sediyono, E. (2017). Pengembangan Model Manajemen Pembelajaran Berbasis TIK di Sekolah Dasar. Kelola: Jurnal Manajemen Pendidikan, 4(1), 59-71. https://doi.org/10.24246/j.jk.2017.v4.i1.p59-71 
Muhid, A., Asnawi, A., \& P, R. S. S. A. (2018). Pendidikan Moral melalui Pembelajaran Kitab Alfiyah ibn Malik di Pondok Pesantren Langitan Tuban. Jurnal Pendidikan Agama Islam (Journal of Islamic Education Studies), 6(1), 106-126. https://doi.org/10.15642/jpai.2018.6.1.106-126

Mu'izzuddin, M., Juhji, \& Hasbullah. (2019). Implementasi Motode Sorogan dan Bandongan dalam Meningkatkan Kemampuan Membaca Kitab Kuning. Geneologi PAI, 6(1), 43-50.

Mulyasa, E. (2000). Standar Kompetensi dan Sertifikasi Guru. Bandung: Remaja Rosdakarya.

Nurtawab, E. (2019). The Decline of Traditional Learning Methods in Changing Indonesia: Trends of Bandongan-Kitāb Readings in Pesantrens. Studia Islamika, 26(3), 511-541. https://doi.org/10.36712/sdi.v26i3.11026

Pusat Bahasa. (2008). Kamus Bahasa Indonesia. Jakarta: Pusat Bahasa Depdiknas. Rohman, F. (2017). Pembelajaran Fiqih Berbasis Masalah melalui Kegiatan Musyawarah di Pondok Pesantren Al-Anwar Sarang Rembang. Al-Tadzkiyyah: Jurnal Pendidikan Islam, 8(2), 179-200. https://doi.org/10.24042/atjpi.v8i2.2124

Rohman, F. (2019). Buku Ajar Strategi Pembelajaran PAI. Jepara: Penerbit FTIK Unisnu Jepara.

Rukajat, A. (2018). Manajemen Pembelajaran. Yogyakarta: Deepublish.

Stoner, J. A. F., Freeman, R. E., \& Gilbert, D. R. (1996). Manajemen terj. Alexander Sindoro. Jakarta: PT. Prenhallindo.

Sufyarma. (2004). Kapita Selekta Manajemen Pendidikan. Bandung: Alfabeta. Syukur, F. (2011). Sejarah Peradaban Islam. Semarang: Pustaka Rizki Putra. Tunggal, A. W. (1993). Manajemen (Suatu Pengantar). Jakarta: Rineka Cipta. Wibowo. (2012). Manajemen Perubahan (3rd ed.). Jakarta: Rajawali Press. 
IOZ | Tarbawi : Jurnal Pendidikan Islam Vol. 17. No. 2. Juli - Desember 2020 